Neuroepidemiology 2012;39:70-71

DOI: $\underline{10.1159 / 000338788}$

\section{Month of Birth Does Not Seem to Interfere with the Development of Multiple Sclerosis Later in Life in Brazilian Patients}

\begin{abstract}
Yára Dadalti Fragoso ${ }^{\mathrm{b}}$, Kirsty D. Shearer ${ }^{\mathrm{a}}$, Tarso Adonic, Soniza Vieira Alves-Leon ${ }^{\mathrm{e}}$, Joseph Bruno Bidin Brooks", Elizabeth Regina Comini-Frota ${ }^{f}$, Alfredo Damascenog, Benito Damasceno", Ana Patrícia Peres Fiore ${ }^{\text {h, }}$ Maria Cristina Baptista Giacomoi, Sidney Gomes ${ }^{\mathrm{d}}$, Marcus Vinicius Magno Gonçalvesj, Damacio Ramón Kaimen-Macielk, Katia Lin', Josiane Lopesk, Juarez Silva Lopes ${ }^{m}$, Giselle Lourenço', Gabriela Machado', Luiz Domingos Melges ${ }^{n}$, Nívea de Macedo Oliveira Morales ${ }^{\circ}$, Rogério Rizo Morales ${ }^{\circ}$, Marcos Moreira ${ }^{p}$, Janaina Silveira Noa ${ }^{m}$, Celso Luis da Silva Oliveira ${ }^{b}$ Regina Maria Papais-Alvarenga ${ }^{\mathrm{e}}$, Monica Parolin ${ }^{\mathrm{q}}$, João Batista Ribeiror, Sonia Beatriz Félix Ribeiro ${ }^{r}$, Heloisa Ruocco ${ }^{\mathrm{s}}$, Fabio Siquinelit

a Institute of Medical Sciences, University of Aberdeen, Aberdeen, UK; ${ }^{\mathrm{b}}$ Department of Neurology, Universidade Metropolitana de Santos, 'Department of Neurology, Hospital Heliopolis, and ${ }^{\mathrm{d}} \mathrm{Hospital}$ Beneficencia Portuguesa and Hospital Paulistano, São Paulo, ${ }^{e}$ Department of Neurology, Universidade Federal do Rio de Janeiro, Rio de Janeiro, f Department of Neurology, Universidade Federal de Minas Gerais, Minas Gerais, 9Department of Neurology, Universidade Estadual de Campinas, Campinas, ${ }^{\mathrm{h}}$ Cruzada Bandeirante São Camilo Assistência Médico Social, 'Neurology Clinic, and ${ }^{\mathrm{j} C l i n i c a}$ Neurologica de Joinville, Joinville, ${ }^{k}$ Department of Neurology, Universidade Estadual de Londrina, Londrina, 'Department of Neurology, Universidade Federal de Santa Catarina, Santa Catarina, m Neurology Clinic, Santa Maria, ${ }^{\mathrm{n}}$ Department of Neurology, Faculdade de Medicina de Marilia, Marilia, ${ }^{\circ}$ Department of Neurology, Universidade Federal de Uberlandia, Uberlandia, ${ }^{\mathrm{P} C l i n i c a l}$ Neuroimmunology Unit, Hospital Therezinha de Jesus, FCMS Suprema,

Juiz de Fora, ${ }^{9}$ Neurology Clinic, Curitiba, ${ }^{r}$ Department of Neurology, Universidade Federal do Triangulo Mineiro, Uberaba, ${ }^{\mathrm{s} N e u r o l o g y}$ Clinic, Jundiai, and ${ }^{\mathrm{t}}$ Medical School, Hospital Santa Isabel, Universidade Regional de Blumenau, Blumenau, Brazil
\end{abstract}

We read with great interest, the paper from Givon et al. [1], reporting on the absence of a relationship between an individual's month of birth and development of multiple sclerosis (MS) in Israel. The authors considered that the relatively stable weather conditions in Israel allow for adequate sun exposure throughout the year. However, it has been suggested that the month in which a person is born and the development of MS might be related through the influence of the mother's exposure to sunlight during pregnancy, possibly affecting vitamin $\mathrm{D}$ metabolism. This theory has been supported by data from several countries with pronounced winters [2-7], confirming that more individuals with
MS were born at the end of the winter season. In other studies, the season of birth did not seem to interfere with the development of MS later in life, despite severe winters [10].

The present study aimed to assess whether the month of birth might influence the development of MS in a specific geographic region of Brazil. The study was approved by the institutions participating in data collection. Information on the month of birth from 2,030 MS patients was obtained from Brazilian MS units in 15 cities between the latitudes of $18^{\circ} 55^{\prime} 23^{\prime \prime} \mathrm{S}$ and $29^{\circ} 43^{\prime} 23^{\prime \prime} \mathrm{S}$. The typical climate of the region within these latitudes is tropical and subtropical, with mild winters and hot summers. A control group of nonneurological patients and employees from different hospital units was created with 2,030 individuals.

The month of birth of MS cases and control individuals is shown in figure la and showed no significant differences when compared using $\chi^{2}$ analysis. Similarly, no differences were observed when the data set was divided into the annual seasons (fig. 1b).

Our results are similar to those of Givon et al. [1]. Israel and Brazil share similar daylight and temperatures throughout the year. These findings may indeed reinforce the idea that stable weather without severe and dark winters might exclude the seasonal distribution of MS patients born in different periods of the year.

\section{Disclosure Statement}

The present study was carried out without financial support from private or governmental grants. The authors have no conflicts of interest to declare regarding this work.

\section{References}

$\checkmark 1$ Givon U, Zeilig G, Dolev M, Achiron A: The month of birth and the incidence of multiple sclerosis in the Israeli population. Neuroepidemiology 2012;38:64-68.

- 2 Templer DI, Trent NH, Spencer DA, Trent A, Corgiat MD, Mortensen PB, Gordon M: Season of birth in multiple sclerosis. Acta Neurol Scand 1992;85:107-109.

3 Wiberg M, Templer DI: Season of birth in multiple sclerosis in Sweden: replication of Denmark findings. J Orthomol Med 1994;9:71-74.

-4 Bharanidharan P: Monthly distribution of multiple sclerosis patients' births. Int J Biometeorol 1997;40:117-118.

5 Willer CJ, Dyment DA, Sadovnick AD, Rothwell PM, Murray CJ, Ebers GC: Timing of birth and risk of multiple sclerosis. BMJ 2005;330:120.

-6 Staples J, Ponsonby AL, Lim L: Low maternal exposure to ultraviolet radiation in pregnancy, month of birth, and risk of multiple sclerosis in offspring: longitudinal analysis. BMJ 2010;340:c1640.

7 Salzer J, Svenningsson A, Sundström P: Season of birth and multiple sclerosis in Sweden. Acta Neurol Scand 2010;122:70-73.

8 Bayes HK, Weir CJ, O'Leary C: Timing of birth and risk of multiple sclerosis in the Scottish population. Eur Neur 2010;63:36-40.

-9 Saastamoinen KP, Auvinen MK, Tienari PJ: Month of birth is associated with multiple sclerosis but not with HLA-DR15 in Finland. Mult Scler 2012;18:563-568.

10 Sadovinick AD, Yee IM: Season of birth in multiple sclerosis. Acta Neurol Scand 1994;89:190-191.

\section{KARGER}

Fax +41613061234 E-Mail karger@karger.ch www.karger.com
() 2012 S. Karger AG, Basel

0251-5350/12/0391-0070\$38.00/0

Accessible online at:

www.karger.com/ned
Y.D. Fragoso

Department of Neurology, Medical School, UNIMES

Rua da Constituição 374

Santos, SP 11015-470 (Brazil)

Tel. +55 133226 3400, E-Mail yara@ bsnet.com.br 

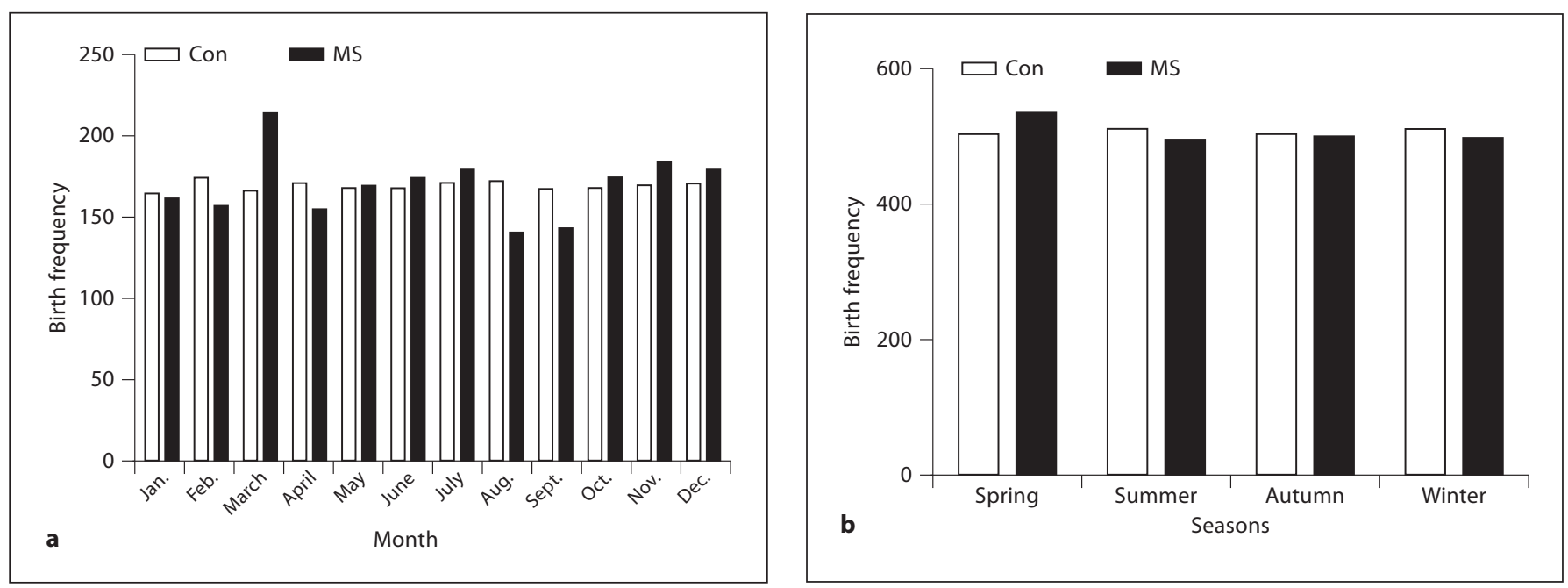

Fig. 1. Month of birth of Brazilian cohort of control and MS patients: number of births recorded in individual months between 1997 and 2012 (a) and distribution of births throughout the annual seasons (b). No significant differences were observed. 